Chirurgia (2020) 115: 341-347

No. 3, May - June

Copyright@ Celsius

http://dx.doi.org/10.21614/chirurgia.115.3.341

\title{
Immediate Postoperative Results in the Surgical Treatment of Neoplastic Pericarditis - 76 Consecutive Cases
}

\author{
Elena Jianu', Natalia Motas ${ }^{1,2 *}$, Mihnea Davidescu ${ }^{1,2}$, Ovidiu Rus $^{1}$, Corina Bluoss', Veronica Manolache', \\ Madalina Iliescu', Teodor Horvat ${ }^{1,2}$
}

${ }^{1}$ Clinic of Thoracic Surgery, Institute of Oncology "Prof. Dr. Al. Trestioreanu", Bucharest, Romania

¿University of Medicine and Pharmacy "Carol Davila", Bucharest, Romania

Corresponding author:

Natalia Motas, MD

Sos. Fundeni 252, sector 2

022328, Bucharest, Romania

E-mail: natalia.motas@gmail.com

Received: 27.03.2020

Accepted: 06.05.2020

\section{Rezumat}

Tratamentul chirurgical al pericarditelor maligne - rezultate postoperatorii imediate în 76 de cazuri consecutive

Introducere: Epansamentul pericardic, acumularea de lichid în sacul pericardic, se poate dezvolta în orice tip de cancer. A fost constatat la până la $20 \%$ din pacientii oncologici.

Metodă:Am efectuat un studiu retrospectiv a pacienților cu pericardita, internați în clinica noastră în anii 2010-2015. Am inclus în studiu 76 de pacienți consecutivi care au avut indicație de drenaj pericardic: peri-cardocenteza, fereastra pericardică subxifoidiană, fereastra pericardică paraxifoidiană stângă, chirurgie toracică video-asistată (CTVA) sau chirurgie toracică clasică. Am avut pacienți cu vârste cuprinse între 28 şi 83 de ani, dintre care 23 pacienți au fost admişi cu tamponadă cardiacă. Rezultate: Supraviețiirea postopertorie imediata a fost $97.3 \%$. Supraviețirea postoperatorie la 30 de zile - $81.5 \%$.

Concluzii: Prognosticul imediat al pacienților cu pericardită neoplazică este influențat de sindromul debitului cardiac scăzut postoperator (Low-Cardiac-Output-Syndrome - LCOS), care rămâne principala cauză de mortalitate. Prognosticul pe termen lung este legat de tipul neoplaziei. Cea mai eficientă tehnică chirurgicală, cu cea mai mică rată de recurența, este fereastra pericardo-pleurală efectuată toracoscopic sau CTVA. Pericardocenteza are rata de recurență cea mai ridicată - 90\% - şi este asociată cu rate crescute de complicații cardiace şi de mortalitate

Cuvinte cheie: efuziune pericardică, pericardită neoplazică, 
tamponadă cardiacă, chirurgie toracică video-asistată, (CTVA), fenestrare pericardică, fereastră pericardică subxifoidiană, fereastră pericardică paraxifoidiană

\begin{abstract}
Introduction: Pericardial effusion, accumulation of fluid in the pericardial sac, may develop in any type of cancer. It was revealed in up to $20 \%$ of oncological patients.

Method: We made a retrospective study of patients with pericardial efusion presented in our clinic between 2010 and 2015. We included 76 consecutive patients with indication for pericardial drainage - we performed on them 80 surgical procedures: pericardocentesis, subxiphoid pericardial window, left paraxifoidian pericardial window, intercostal video-assisted thoracic surgery (VATS) pericardial fenestration, and classical thoracic surgery (fenestration or partial pericardiectomy). We had patients with ages between 28 and 83 years. 23 patients were admitted with cardiac tamponade.

Results:The immediate postoperatory survival is $97.3 \%$ and the 30 -days-postoperatory survival is $81.5 \%$. The immediate postoperatory mortality is $2.7 \%$ and the 30 -days-postoperatory mortality is $8.5 \%$.

Conclusions: The immediate prognosis of the patient with malignant pericardial effusion is influenced by the risk of postoperative Low-Cardiac-Output-Syndrome (LCOS), or pericardial decompression syndrome (PDS), which remains the main cause of mortality. The long-term prognosis is related to the type of malignant tumor. The most effective tehnique with the lowest rate of recurrence is pericardo-pleural window done thoracoscopically/ by VATS; pericardocentesis has the highest rate of recurrence $-90 \%$ and is associated with high rates of cardiac complications and mortality.
\end{abstract}

Key words: pericardial effusion, neoplastic pericarditis, cardiac tamponade, video-assisted thoracic surgery (VATS) pericardial fenestration, subxiphoidian pericardial fenestration, paraxiphoidian pericardial fenestration

\section{Introduction}

Pericardial effusion is an accumulation of fluid in the pericardial sac. It has been determined that the normal quantity of fluid is less than $50 \mathrm{ml}(1)$.

Patients may develop pericardial effusion in any type of cancer, but most frequently in lung cancer, breast cancer and lymphoma (24 ); the long-term prognosis of those patients depends on their type of malignancy and is not influenced by age, sex, surgical technique of pericardial drainage, or direct interest of the pericardium by the malignant process. Metastatic tumors of the pericardium are 40 times more frequent than primary tumors (5). The incidence of abnormal pericardial fluid in patients with malignancy has been revealed in $1-21 \%$ of patients $(6,7)$.

The rate of fluid accumulation in the pericardium is very important: fast accumulation of small amounts can cause tamponade; slow accumulations of large quantities of fluid in a long period of time can be surprisingly well tolerated (8).

Echocardiography is the main method for pericardial effusion assesment, detecting effusion, location and hemodynamic effect, concomitant heart or pericardial disease $(5,9)$. The CT scan visualizes the presence, topography and thickness of the pericardial effusion, allowing the surgeon to choose the best surgical aproach $(3,10)$. 


\section{Materials and Methods}

We studied retrospectively all the patients with pericardial efusion presented in our clinic between 2010 and 2015. We included in the study 76 patients who had indication for pericardial drainage. All patients had an underlying malignancy. There were 3 patients who had recurrence, and had to be submitted to another procedure to evacuate the pericardial fluid.

The surgical procedures were chosen according with the clinical state of the patient, using local or general anesthesia: pericardocentesis, subxiphoid pericardial window, left paraxifoidian pericardial window, intercostal video-assisted thoracic surgery VATS, or clasical thoracic surgery.

\section{Results}

The 76 patients were 43 men (55\%) and 34 women (45\%), with ages between 28 and 83 years. We observed an increased procentage of smokers $(61 \%)$ in patients with pericardial effusion.

Thirty procent of the patients (23 cases) presented with cardiac tamponade (Fig. 1) and we performed pericardial drainage in emergency; some of them needed correction of coagulation status, severely altered after chemotherapy or by the treatment of associated diseases.

Beside the pericardial drainage there were performed associated surgical procedures in 26 patients. We had 23 cases with pericardial drainage and chest tube drainage of the pleural fluid; in 3 cases we performed a pericardo-pleural window together with a pulmonary resections: 2 wedge-resections and one lobectomy.

Three patients developed recurrence of the pericardial fluid and needed reintervention: two patients had one recurrency, and one patient had 2 recurrencies. The rate of recurrence was $3.89 \%$.

Regarding the underlying malignancy, the largest number of patients have developed pericardial effusion during the evolution of lung cancer - 54, followed by breast cancer 16 , and 7 patients had another type of cancer: uterin cervical cancer - 3, Hodgkin lymphoma - 1, colon - 1, lip - 1, ovary - 1 (Fig. 2).

Patients underwent different types of surgery, according to clinical status, topography of the fluid and presence of pleural fluid (Fig. 3). There was one female patient, known with stage IV cervix cancer, with right pleural and pericardial effusion at admission, which refused the pericardial drainage and accepted only the right chest tube drainage, along with the intesive medical treatment. Unfortunately

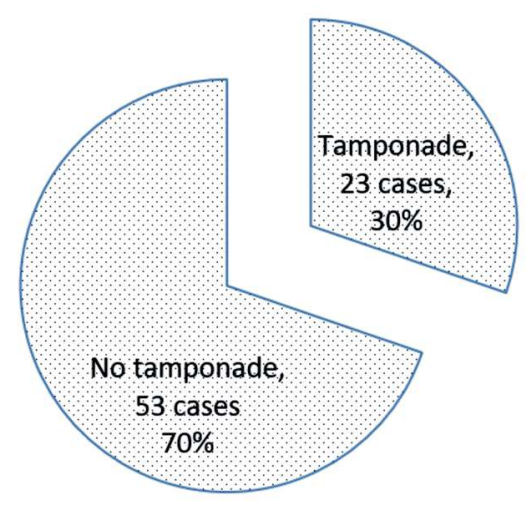

Figure 1. Distribution of cases with pericardial effusion according to the presence of cardiac tamponade at admission

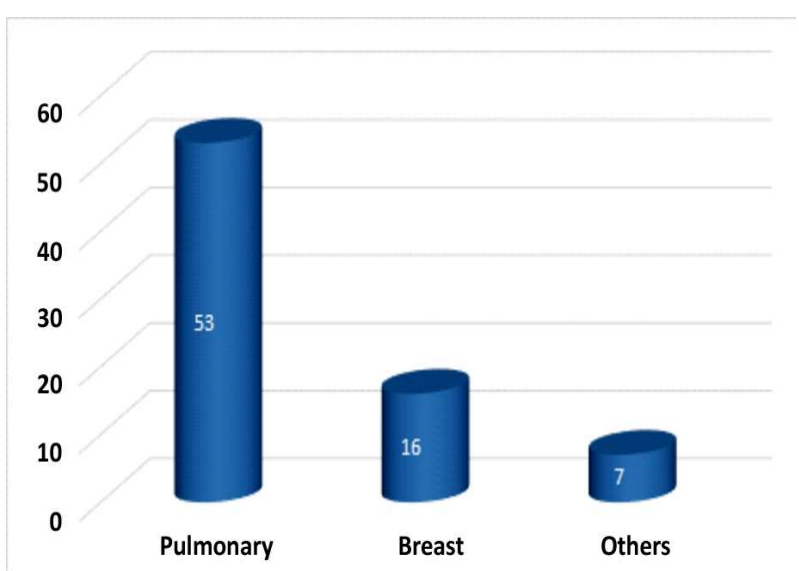

Figure 2. Underlying malignancies in patients with pericardial effusion from the lot of study 


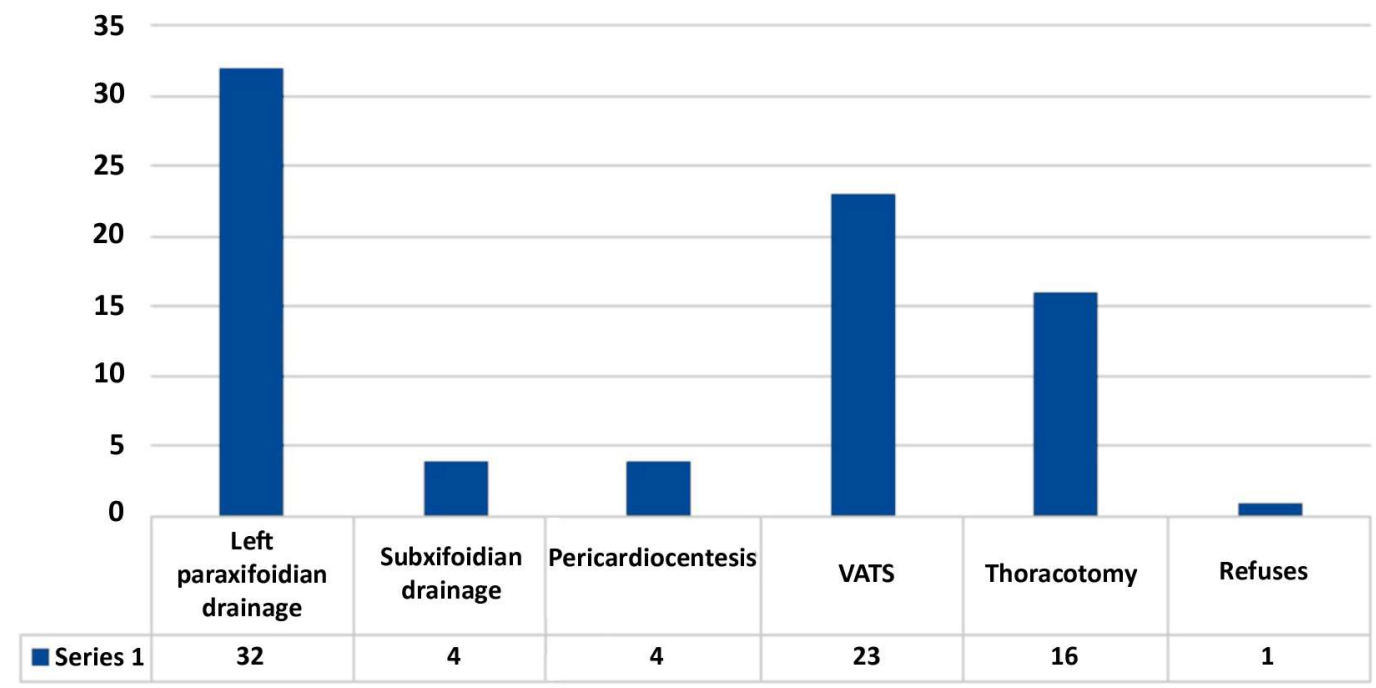

Figure 3. Type of surgical procedure performed for pericardial drainage in the lot of study. VATS = Video-Assisted-Thoracic-Surgery

her survival was only of 10 days.

The immediate postoperatory survival is $97.3 \%$. We had two patients (with stage IV cancers) who developed severe bradicardia and cardiac arrest at pericardocentesis, during the evacuation of the pericardial fluid.
Specific resuscitation measures were performed; both patients died within next 24 hours. The immediate postoperatory mortality is $2.7 \%$.

At one month survival is $81.5 \%$ (Table 1 ). The 30 -days-postoperatory mortality is $8.5 \%$.

Table 1. Immediate survival of oncologic patients with pericardial drainage, according to various variables

\begin{tabular}{|c|c|c|c|c|}
\hline \multirow[t]{2}{*}{ Variables } & \multirow[t]{2}{*}{ Pacients (n) } & \multicolumn{2}{|c|}{ Rate of survival (\%) } & \multirow[t]{2}{*}{ Value $p$} \\
\hline & & $48 \mathrm{~h}$ & 1 month & \\
\hline Gender & & & & 0.09 \\
\hline Masculin & 43 & 95.5 & 79.5 & \\
\hline Feminin & 34 & 100 & 88.8 & \\
\hline$\overline{\mathrm{Age}}$ & & & & 0.61 \\
\hline$>65$ Years & 10 & 100 & 70 & \\
\hline$<65$ years & 67 & 97.1 & 85.7 & \\
\hline Underlying malignancy & & & & 0.34 \\
\hline Pulmonary & 53 & 98.2 & 87.5 & \\
\hline Breast & 16 & 94.1 & 82.3 & \\
\hline Others & 7 & 100 & 57.1 & \\
\hline Aspect of pericardial fluid & & & & 0.05 \\
\hline Hemoragic & 38 & 95 & 85 & \\
\hline Serous & 31 & 100 & 83.8 & \\
\hline Serohematic & 7 & 100 & 87.5 & \\
\hline Smoking status & & & & 0.06 \\
\hline Smoker & 46 & 97.9 & 79.1 & \\
\hline Nonsmoker & 30 & 96.8 & 87.5 & \\
\hline Cardiac tamponade & & & & 0.11 \\
\hline Present & 23 & 91.3 & 78.2 & \\
\hline Not present & 57 & 100 & 2.4 & \\
\hline
\end{tabular}




\section{Discussions}

Pericardial effusion may appear frequently in patients with malignancies. Heart and pericardium metastases can be detected in autopsy in $15-20 \%$ of cancer patients (11) and nonmalignant pericardial effusion in $7 \%$ of patients (12). In our study, as we found in the literature $(3,10,13)$, the most frequent type of cancer in patients with pericardial effusion was lung cancer, perhaps because lung cancer is the most frequent malignancy that we encounter in our daily practice and in which we have expertise (14-18). Most of those patients are severily affected by the evolution and complications of their malignancy (which may be multiple), by oncological treatments and their side effects, by their disfunctional immunological status and associated diseases (cardiac, renal, hepatic etc.).

Currently there is no standard effective treatment for malignant pleural effusion (19).

If the measured pericardial effusion is less than $1 \mathrm{~cm}$, it ussually does not progress (12). Patients without clinical symptoms shoud be kept under close observation, and treated for the underlying cancer. This does not affect mortality (12).

For pericardial drainage the following procedures can be used: pericardiocentesis, balloon pericardiotomy, subxiphoid or paraxiphoid window (Fig. 4), video-assisted thoracic surgery (VATS) pericardo-pleural fenestration (Fig. 5), thoracotomy pericardial window (Fig. 6), pericardialperitoneal window, and pericardiectomy via sternotomy or thoracotomy (20). The goals of the pericardial drainage in oncological patients are to relieve symptoms, to obtain fluid and tissue for diagnosis, and to insure a low recurrence $(2,20)$. In our study we performed almost all of those surgical procedures (Fig. 3).

In 32 cases we performed the paraxiphoidian approach (Fig. 4) developed and published by us in 2010 (11). The paraxiphoidian pericardial drainage can be performed under local anesthesia, knowing that in tamponade the blood pressure is

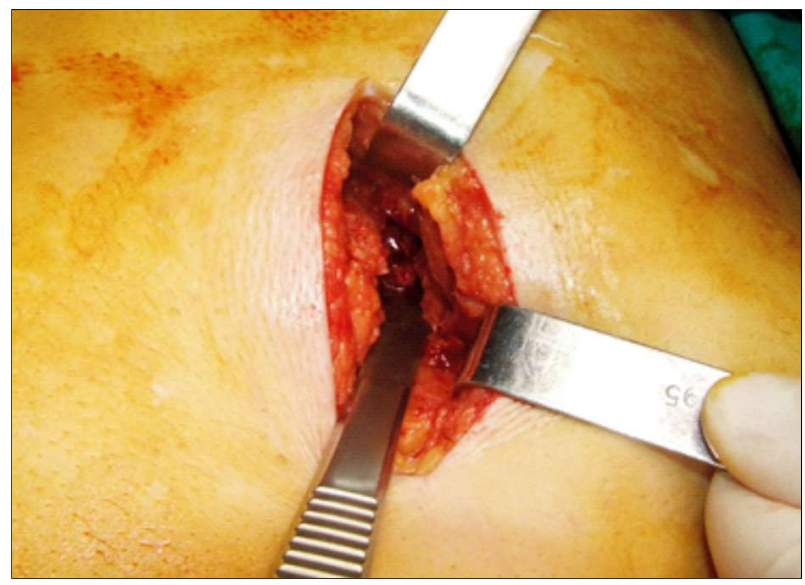

Figure 4. Left paraxifoidian approach of the pericardium: skin incision on left side of the xiphoid process, left rectus abdominus de-inserted from the xiphoid; the pericardium is entered and evacuated; then the pericardial fenestration is performed

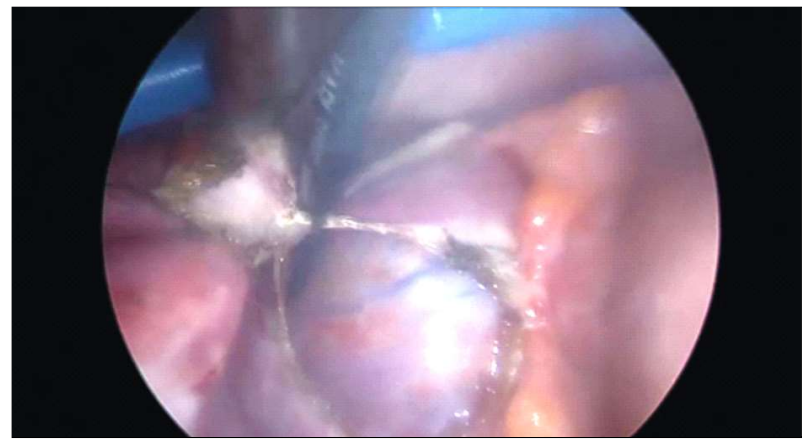

Figure 5. Pericardo-pleural window performed by left uniportal VATS (Video-Assisted-Thoracic-Surgery) - the fenestration is created (aprox. $4 \mathrm{~cm}^{2}$ ) and the pericardial fragment is almost completly detached using the thoracoscopic cautery. Uniportal VATS is performed through a unique $3-3.5 \mathrm{~cm}$ incision

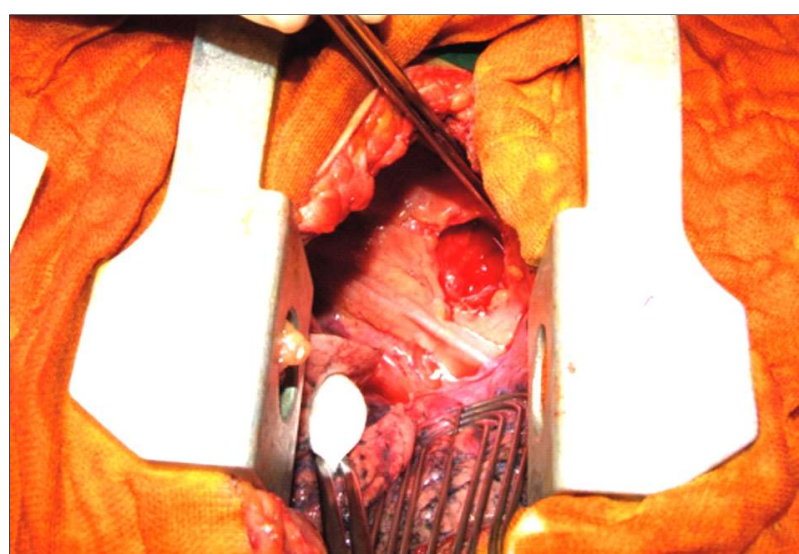

Figure 6. Pericardial window performed anterior to the frenic nerve, on the left side, by thoracotomy (open or classic thoracic surgery) 
maintained by increased symphathetic tonus, which is interrupted at the induction of the general anesthesia, leading to hemodynamic collapse (11).

In 4 cases we performed transthoracic left intercostal pericardial needle drainage using ultrasound guidance because no other point of access was available (subxiphoidian or parasternal left or right), due to the anatomy modification caused by the underlying disease. Three of those 4 patients were in tamponade and the transthoracic pericardiocentesis was performed in emergency. Such difficult cases emphasize the need to perform a thoracic CTscan in addition to echocardiography in order to assess correctly the anatomical modifications and the intrathoracic lesions due to malignancy and oncological treatment (especially radiotherapy).

Malignancy is a predictive factor of postoperative Low-Cardiac-Output-Syndrome (LCOS) after pericardial drainage (21). To prevent this potential lethal complication, it is mandatory to evacuate very slowly the pericardial fluid, to closely monitor the heart and to administrate intravenous inotropic support as soon as needed (3).

Immediate postoperative mortality in our study was $2.7 \%$ and 30 -days postoperative mortality was $8.5 \%$ - the values are very good compared to some published: $36 \%$ operative mortality and $32 \%$ at 30 days in malignant patients (22).

Studies have shown that the most effective tehnique with the lowest rate of recurrence is pericardo-pleural window done thoracoscopically/ by video-assisted thoracic surgery (VATS); the pericardial drainage done by thoracotomy and pericardo-peritoneal window have a $10 \%$ rate of recurrence. Pericardocentesis has the highest rate of recurrence $90 \%$ - and is associated with high rates of mortality and cardiac complications (2).

In our study we had 3 patients with 4 recurrencies: 2 recurrencies after left paraxifoidian drainage (solved by subxifoidian drainage, and by VATS pericardo-pleural fenestration, respectively), 1 case after subxifoidian drainage (solved by open partial peri- cardiectomy) and 1 case after pericardopleural window (solved by paraxiphoidian drainage). All 3 patients were stage IV malignancy (lung and breast. The rate of recurrence was $3.89 \%$. In the literature we found published a recurence rate of $13.6 \%$ (22) and of $19 \%$ (23) in patients with malignancy.

\section{Conclusions}

Pericardial effusion in neoplastic patients should be evaluated by cardiac ultrasound and, whenever possible, by thoracic CT-scan, in order to evaluate correctly the intrathoracic modifications due to malignancy and oncological treatment, and to choose the best pericardial approach in every case.

The immediate prognosis of the patient with malignant pericardial effusion is influenced by the risk of postoperative Low ${ }^{-}$ Cardiac-Output Syndrome (LCOS), which remains the main cause of mortality. Slow evacuation, heart monitoring and inotropic support lower the risk of the LCOS and improve the immediate postoperatory survival.

The long-term prognosis overlaps the prognosis of the underlying malignancy.

\section{Conflict of Interest}

None to declare.

\section{References}

1. Horvat T, Fudulu D. Fiziologia pericardului. In "Pericardul". Bucuresti: Editura Academiei Romane; 2015. p. 55- 63.

2. Singh D, Katlic MR: Malignant Pericardial Effusions. In "General Thoracic Surgery" 7th Edition, sub red. Shields TW. Philadelphia: Lippincott Williams \& Wilkins; 2009. p. 885-890.

3. Horvat T, Ciuche A. Pericarditele Maligne. In "Tratat de Chirurgie" sub red. Popescu I. volumul IV "Chirurgie Toracica" sub red. Horvat T. Bucuresti: Editura Academiei Române; 2008. p. 347- 357.

4. Imazio M, Colopi M, De Ferrari GM. Pericardial diseases in patients with cancer: contemporary prevalence, management and outcomes. Heart. 2020;106(8):569-574.

5. Maisch B, Seferović PM, Ristić AD, Erbel R, Rienmüller R, Adler Y, et al. Guidelines on the Diagnosis and Management of Pericardial Diseases Executive Summary: The Task Force on the Diagnosis and Management of Pericardial Diseases of the European Society of Cardiology. European Heart Journal. 2004;25(7):587-610.

6. Kazantzis T, Bibas BJ, Dela-Vega AJ, Nabuco P, Lauricell LL, PegoFernandes PM, Terra RM. Predictors of hospital discharge in cancer patients with pericardial effusion undergoing surgical peri- 
cardial drainage. J Surg Oncol. 2019;119:143-147.

7. Cullinane CA, Paz IB, Smith D, Carter N,Grannis FW. Prognostic Factors in the Surgical Management of Pericardial Effusion in the Patient With Concurrent Malignancy. Chest. 2004;125(4):13281334.

8. Roberts JR, Kaiser LR. Pericardial Procedures. In "Mastery of Cardiothoracic Surgery" 2nd edition. Philadelphia: Lippincott Williams \& Wilkins; 2007. p. 254-261.

9. Refaat MM, Katz WE. Neoplastic Pericardial Effusion. Clin. Cardiol. 2011;34(10):593-598.

10. Ciuche A, Nistor C, Motas C, Horvat T. Chirurgia Miniinvaziva in Tratamentul Pleuro-Pericarditelor Maligne. Chirurgia (Buc). 2012;107(2):206-212.

11. Motas C, Motas N, Rus O, Horvat T. Left Paraxifoidian Aproach For Drainage Of Pericardial Effusions. Interact Cardiovasc Thorac Surg. 2010;10(1):4-6.

12. Laham RJ, Cohen DJ, Kuntz RE, Baim DS, Lorell BH, Simons M. Pericardial Effusion In Patients With Cancer: Outcome With Contemporary Management Strategies. Heart. 1996;75:67-71.

13. Oshima Y, Tabata T, Nonomura R, Sasaki T, Mitomo H, Ishibashi N, et al. Pericardial Fenestration and Multidisciplinary Treatment to Improve the Prognosis of the Malignant Pericarditis Due to Lung Cancer. Kyobu Geka. 2020;73(1):63-67. Japanese

14. Motas N, Motas C, Davidescu M, Bluoss C, Rus O, Bobocea A, et al. Solitary pulmonary nodule-150 resected cases. Chirurgia (Buc), 2010;105(2):195-201.

15. Nistor C, Motas N, Motas C, Davidescu M, Tetu M, Vasilescu F, et al. Surgical procedures in broncho-pulmonary carcinoids - our experience of 92 consecutive cases. Acta Endo (Buc). 2009;5(3): $359-370$.

16. Zhang J, Zhang $Q$, Chen $X$, Zhang N. Management of neoplastic pericardial disease. Herz. 2019 Jul 11. doi: 10.1007/s00059-0194833-4. (Epub ahead of print)

17. Dediu M, Ion O, Ion R, Alexandru A, Median D, Gal C, et al. Impact of adjuvant chemotherapy in stage IB non-small-cell lung cancer: An analysis of 112 consecutively treated patients. J BUON. 2012; 17(2):317-22.

18. Rus O, Motas C, Motas N, Achim D, Horvat T. Bronchoanastomotic and bronchoplastic resections in pulmonary malignancy retrospective study 2000 - 2009. Chirurgia(Buc). 2014;109(4):455-60.

19. Motas N, Davidescu M, Manolache V, Burlacu A, Horvat T. Null 30Days Mortality After 72 Consecutive Left Open Pneumonectomies for Lung Cancer. J Thorac Oncol. 2017;12(11)S2:S2350-S2350.

20. Jianu E, Motas N, Nicolae R, Dumitrascu 0, Horvat T. The surgical management of pericardial effusions in cancer patients. Proc.Rom.Acad., Series B. 2015;Supplement 1:112-115.

21. Sabzi F, Faraji R. Predictors of Post Pericardiotomy Low Cardiac Output Syndrome in Patients With Pericardial Effusion. J Cardiovasc Thorac Res. 2015;7(1):18-23.

22. Balla S, Zea-Vera R, Kaplan RA, Rosengart TK, Wall MJ, Ghanta RK. Mid-Term Efficacy of Subxiphoid Versus Transpleural Pericardial Window for Pericardial Effusion. J Surg Res. 2020;252:9-15. Available online 23 March 2020

23. Di Liso E, Menichetti A, Dieci MV, Ghiotto C, Banzato A, Bianchi A, et al. Neoplastic Pericardial Effusion: A Monocentric Retrospective Study. J Palliat Med. 2019;22(6):691-695 